\title{
PENGGUNAAN PENDEKATAN PROBLEM SOLVING UNTUK MENINGKATKAN HASIL BELAJAR PESERTA DIDIK PADA PEMBELAJARAN IPS DI KELAS IV SDN 21 BATANG ANAI KABUPATEN PADANG PARIAMAN
}

\author{
Yulizarni
}

Dinas Pendidikan Kabupaten Padang Pariaman

$\ggg$ e-mail: yulizarni_a@yahoo.com

\begin{abstract}
Abstratc
This research was that aims to improve the learning outcomes of social educatio using the approach problemsolving in class IV SDN 21 Batang Anai. The approach used a qualitative and quantitative. Subjek of research were teacher and students in class IV SDN 21 Batang Anai with 23 students.This research did in SDN 21 Batang Anai Kab.Padang Pariaman The first cyele was 66,95\% increase to 81,30\% in the second cyecle.Thus, approach problem solvingcan improve the learning outcomes of social education in class IV SDN 21 Batang Anai Kab. Padang Pariaman.
\end{abstract}

Keyword: Sosial learning out cames, Problem Solving Approach

Copyright (C) 2017 IICET - All Rights Reserved

Indonesian Institute for Counseling, Education and Therapy (IICET)

\section{PENDAHULUAN}

Pendekatan merupakan cara atau usaha dalam mendekati atau menyampaikan sesuatu hal yang diinginkan. Begitu juga dalam proses pembelajaran, pendekatan merupakan titik tolak atau acuan bagi seorang guru terhadap pembelajaran yang akan dilakukan. Menurut Depdiknas (dalam Alben, 2006:69) "Pendekatan merupakan suatu rangkaian tindakan yang terpola atau terorganisir, berdasarkan prinsip-prinsip tertentu seperti: dasar filosofis, prinsip psikologis, prinsip didaktis yang terarah secara sistimatis pada tujuan-tujuan yang hendak dicapai”.

Pendekatan problem solving ini dapat juga digunakan dalam mata pelajaran IPS di SD. Hal ini sesuai dengan tujuan pembelajaran IPS menurut Depdiknas (2006: 575) sebagai berikut:

(1) mengenal konsep-konsep yang berkaitan dengan kehidupan masyarakat dan lingkungannya. (2) memiliki kemampuan dasar untuk berpikir logis dan kritis, rasa ingin tahu, inkuiri, memecahkan masalah dan keterampilan dalam kehidupan sosial. (3) memiliki kesadaran dan komitmen terhadap nilai-nilai sosial dan kemanusiaan. (4) memiliki kemampuan berkomunikasi, bekerja sama dan berkompetensi dalam bermasyarakat yang majemuk di tingkat lokal, nasional dan global. 
Untuk mewujudkan tujuan pembelajaran IPS di atas salah satunya dapat dicapai dengan menggunakan pendekatan problem solving dalam proses pembelajaran. IPS merupakan salah satu mata pelajaran yang dirancang secara sistimatik terpadu, komprehensif, untuk mencapai tujuan yang terdapat dalam mata pelajaran tersebut. Di samping itu IPS juga mendidik dan memberi bekal kemampuan dasar kepada siswa untuk mengembangkan diri sesuai bakat, minat, kemampuan dan lingkungan sekitarnya serta membahas hubungan antara manusia dan lingkungan tempat siswa tumbuh dan berkembang dengan berbagai permasalahan yang terjadi di lingkungan sekitarnya.

Penggunaan pendekatan problem solving pada mata pelajaran IPS dapat dilakukan dengan cara mengaktifkan siswa selama proses pembelajaran, karena selama proses pembelajaran siswa menyadari, merumuskan, menganalisa, merumuskan hipotesa atau jawaban sementara terhadap masalah, mencari data sampai pada penarikan kesimpulan terhadap suatu masalah. Dalam pendekatan problem solving siswa dihadapkan kepada berbagai macam problema atau masalah, dengan demikian diharapkan siswa berusaha mengerahkan segala kemampuan yang dimiliki baik pikiran, perasaan serta semangat untuk mencari pemecahan dari masalah yang dihadapinya sampai siswa tersebut menemukan suatu kesimpulan dari masalah yang terjadi.

Pendekatan problem solving ini sangat baik diberikan dalam pembelajaran IPS di SD, sebab dalam Kurikulum Tingkat Satuan Pendidikan (KTSP) ada beberapa materi yang cocok menggunakan pendekatan problem solving diantaranya materi dengan Standar Kompetensi mengenal sumber daya alam, kegiatan ekonomi dan kemajuan teknologi di lingkungan Kabupaten/kota dan propinsi daerah setempat dengan Kompetensi Dasar mengenal perkembangan teknologi produksi, komunikasi dan transportasi serta pengalaman menggunakannya. Untuk menggunakan pendekatan problem solving pada materi di atas siswa dapat melakukannya melalui tahaptahap pada problem solving, yaitu mulai dari menyadari adanya masalah, merumuskan masalah yang berhubungan dengan dampak perkembangan teknologi, menetapkan jawaban sementara dari masalah yang dibahas, mencari data atau informasi yang berhubungan dengan masalah yang dibahas, menguji hipotesis, kemudian menarik kesimpulan.

Berdasarkan hasil observasi dan wawancara yang dilakukan dengan guru kelas IV SDN. 21 Batang Anai proses pembelajaran yang berlangsung selama ini belum sesuai dengan tuntutan kurikulum, dimana pada pembelajaran IPS guru belum sepenuhnya menggunakan pendekatan problem solving pada materi yang berkaitan dengan permasalahan seperti dalam materi dampak negatif perkembangan teknologi. Hal ini disebabkan oleh kurangnya pengetahuan guru tentang penggunaan pendekatan problem solving dalam pembelaran pembelajaran IPS, sehingga dalam proses pembelajaran guru lebih dominan menggunakan metode ceramah, ini mengakibatkan siswa: (1) kurang aktif dalam proses pembelajaran, (2) kurang dapat mengembangkan minatnya, (3) kurang dapat merealisasikan ilmu pada kehidupan nyata, (4) kemampuan berfikir kritis siswa kurang dapat dikembangkan, (5) begitu juga daya nalar siswa dalam menyelesaikan masalah kurang dapat dikembangkan. Hal ini akan berdampak kepada hasil belajar siswa, yaitu hasil belajar menjadi rendah dengan nilai rata-rata 55 pada ujian mid semester di kelas IV SDN 21 Batang Anai.

Dalam proses pembelajaran IPS guru sebaiknya dapat menggunakan pendekatan problem solving agar peserta didik mampu untuk menyelesaikan masalah-masalah yang dihadapinya dalam kehidupan sehari-hari dengan harapan hasil belajar siswa dapat meningkat. Menurut Nurmelia (dalam Rika, 2008:4) dalam penelitiannya menyimpulkan bahwa hasil IPS dengan menggunakan pendekatan problem solving akan meningkatkan hasil belajar siswa dari pada menggunakan cara konvensional atau menggunakan metode ceramah dalam pembelajaran.

Berdasarkan latar belakang masalah yang penulis kemukakan di atas, maka rumusan masalah dalam PTK ini adalah Bagaimana penggunaan pendekatanproblem solving untuk meningkatkan hasil belajar peserta didik dalam pelajaran IPS di kelas IV SDN 21 BatangAnai?

\section{METODOLOGI}

Jenis penelitian yang penulis lakukan adalah Penelitian Tindakan Kelas (PTK). Menurut Mundilarto (2006) ;Joko (2006:94) penelitian tindakan kelas (PTK) adalah" penelitian yang dilakukan oleh guru kelas sendiri dengan jalan merancang,melaksanakan dan merefleksi tindakan secara kolaboratif dan partisipatif dengan tujuan untuk memperbaiki kinerjanya sebagai guru sehingga hasil belajar siswa dapat meningkat".

Prosedur penelitian ini meliputi perencanaan, pelaksanaan, pengamatan, dan refleksi. Penelitian ini dilakukan dengan menggunakan pendekatan kualitatif dan kuantitatif. Data tersebut direduksi berdasarkan 
masalah yang diteliti, diikuti penyajian data dan terakhir penyimpulan dan verivikasi. Tahap analisis yang demikian dilakukan berulan-ulang begitu data selesai dikumpulkan pada setiap pengumpulan data dalam setiap tindakan.

Subjek penelitian ini adalah guru dan siswa kelas IV dengan jumlah siswa 23 orang dengan 12 orang lakilaki dan 11 orang perempuan.Data penelitian ini dikumpulkan dengan menggunakan observasi, dan hasil tes dengan menggunakan lembaran observasi dan lembaran evaluasi.

\section{HASIL DAN PEMBAHASAN \\ SIKLUS I}

Hasil penelitian pada siklus I terdiri dari perencanaan pembelajaran, pelaksanaan pendekatan Problem solvingyang meliputi aktivitas guru dan siswa dan hasil tes belajar siswa yang dilaksanakan pada akhir siklus I

\section{Perencanaan}

Perencanaan tindakan pembelajaran IPS pada siklus I disusun berdasarkan tahap pendekatan Problem dan berpedoman pada kurikulum tingkat satuan pendidikan KTSP dan dituangkan dalam bentuk RPP. Perencanaan pada siklus I disusun dalam 2x pertemuan. Standar Kompetensi (SK) yaitu mengenal sumber daya alam, kegiatan ekonomi, dan maju teknologi di lingkungan kabupaten/kota dan propinsi, sedangkan kompetensi dasarnya adalah mengenal perkembangan teknologi produksi, komunikasi dan transportasi serta pengalaman penggunaannya.

Berdasarkan RPP yang telah disusun, dilakukan penilaiaan terhadap RPP melalui lembaran observasi. Aspek yang diamati dalam penilaian RPP adalah: (1) kejelasan perumusan proses pembelajaran, (2) pemilihan materi ajar, (3) pengorganisasian materi ajar, (4) pemilihan sumber dan media pembelajaran, (5) menyusun langkah-langkah pembelajaran, (6) teknik pembelajaran, (7) kelengkapan instrumen. Dari hasil observasi diperoleh persentase skor yang didapat padasiklus I yaitu $71 \%$.

\section{Pelaksanaan}

Pelaksanaan tindakan pada siklus I belum terlaksana dengan baik. Hal ini terlihat dalam pelaksanaan tindakan masih terdapat beberapa tindakan belum muncul, seperti yaitu pada saatmembangunpengetahua, guru belum memberikan waktu yang cukup untuk siswa berfikir setelah diberikan pertanyaan. Pada proses pembelajaran mengajukan pertanyaan untuk mendorong ,membimbing,dan menilai kemampuan berfikir siswa, guru belum bertanya bersifat menggali pengetahuan siswa. Dalam mengarahkan siswa untuk menyimpulkan pelajaran, guru belum membimbing siswa dalam menyimpulkan pelajaran secara runtun.

Dalam proses pembelajaran guru belum menilai siswa secara langsung.Soal yang diberikan guru belum jelas dan belum mudah dimengerti. Dalam merumuskan masalah guru belum mengajukan yang menggali dan menuntun dengan baik cara merumuskan masalah. Pada tahap merumuskan hipotesis pertanyaan yang diajukan guru belum membantu peserta didik untuk merumuskan perkiraan jawaban.

Siswa kurang menghargai pendapat setiap anggota kelompok, dalam membaca wacana siswa kurang menggali sumber data atau informasi secara efektif dan efisien. Berdasarkan garis besar ,hasil pelaksanaan tindakan siklus I dilihat dari aspek guru dan siswa.Persentase dari aspek guru pada siklus I pertemuan I adalah 69,4\% dengan kualifikasi cukup dan pada pertemuan II meningkat menjadi $84,7 \%$ dengan kualifikasi baik.Persentase dari aspek siswa pada siklus I pertemuan I adalah 70,3\% dengan kualifikasi cukup dan pada pertemuan II meningkat menjadi 85,9\% dengan kualifikasi baik.

\section{Pengamatan}

Pengamatan yang dilakukan pada penelitian ini meliputi pengamatan,terhadap aktifitas guru dan siswa.Berdasarkan hasil observasi pengamatan terhadap Rencana Pelaksanaan Pembelajaran (RPP) pada siklus I pertemuan I adalah $71 \%$ dengan kualifikasi cukup. Peneliti sebagai guru dalam kegiatan pembelajaran pada siklus I pertemuan I adalah 69,4\% dengan kualifikasi cukup dan pada siklus I pertemuan II meningkat menjadi $84,7 \%$ dengan kualifikasi baik, sedangkan terhadap aspek siswa siklus I pertemuan I mendapat nilai 69,4\% dengan kualifikasi cukup dan pada siklus I pertemuan II meningkat menjadi 85\% dengan kualifikasi sangat baik. Hasil belajar siswa pada siklus I adalah 69,4\%.

\section{Refleksi}

Berdasarkan catatan pada lembar observasi dan diskusi peneliti dengan observer pelaksanaan pembelajaran mengenal perkembangan teknologi produksi, komunikasi dan serta pengalaman menggunakannyapada siklus I belum sempurna karena kebiasaan siswa dalam belajar yang masih terbiasa 
menerima informasi dari guru sehingga siswa sulit untuk menyesuaikan diri dengan pendekatan problem solving yang menuntut kemauan siswa untuk melakukan sendiri inti dari materi pembelajaran.

Pelaksanaan pembelajaran IPS dengan pendekatanpada siklus I belum terlaksana dengan baik ,hal ini dapat dilihat dari hasil observasi aktivitas guru dan siswa dalam pelaksanaan pembelajaran. Hasil observasi aktivitas guru dalam pelaksanaan pembelajaran dengan pendekatan problem solving pada siklus I diperoleh nilai rata-rata $77,05 \%$, sedangkan hasil observasi pada aktivitas siswa dalam pelaksanaan pembelajaran IPS pada siklus I diproleh rata-rata nilai $78,1 \%$.

Pelaksanaan evaluasi pada siklus I ini dilakukan guru dengan cara membagikan soal masing-masing siswa. Berdasarkan hasil refleksi, terlihat kalau dalam menjawab soal siswa kebanyakan tidak membaca soal dengan baik karena soal dijawab oleh siswa dalam waktu yang terlalu cepat sehingga banyak siswa yang tidak memahami soal yang diberikan guru. Dari hasil analisis siklus I hasil belajar yang diperoleh siswa hanya mencapai 66,95 dengan persentase ketuntasan 65\%, sedang menurut kunandar (2008:428) ketuntasan yang ideal adalah $75 \%$, dengan demikian dapat disimpulkan bahwa pelaksanaan IPS dengan pendekatan problem solving pada siklus I belum berhasil dan perlu dilanjutkan ke siklus II.

Hasil yang diperoleh siswa dalam pembelajaran,dapat digunakan guru sebagai pedoman dalam menganalisis perkembangan siswa dalam pembelajaran IPS tentang jenis sumber daya alam untuk direncanakan pada siklus II

\section{SIKLUS II}

Hasil penelitian siklus II terdiri dari perencanaan pembelajaran, pelaksanaan pendekatan problem solving yang meliputi aktivitas guru dan siswa dan hasil tes belajar siswa yang dilaksanakan pada akhir siklus II.

\section{Perencanaan}

Perencanaan tindakan pembelajaran IPS pada siklus II disusun berdasarkan tahapan pendekatan problem solvingdengan memperhatikan kekurangan-kekurangan pada siklus I dan berpedoman pada kurikulum tingkat satuan pendidikan (KTSP) dan dituangkan dalam bentuk RPP. Standar Kompetensi (SK) yang dilaksanakan adalah Mengenal sumber daya alam, kegiatan ekonomi, dan kemajuan teknologi di lingkungan kabupaten/kota dan propinsi,sedangkan kompetensi dasar yang dilaksanakan pada siklus II adalah: Mengenal perkembangan teknologi produksi, komunikasi dan transportasi serta pengalaman menggunakannya.

Berdasarkan RPP yang telah disusun dilakukan penilaian terhadap RPP melalui lembaran observasi. Aspek yang diamati dalam penelitian RPP adalah: (1) kejelasan perumusan tujuan proses pembelajaran, (2) pemilihan materi ajar, (3) pengorganisasian materi ajar, (4) pemilihan sumber dan media pembelajaran, (5) Menyusun lankah-langkah pembelajaran, (6) tekhnik pembelajaran,(7) kelengkapan instrumen. Dari hasil observasi tahapan RPP skor yang didapat dalam merancang pelaksanaan pembelajaran dengan pendekatan problem solving pada siklus II yaitu 85,71 .

\section{Pelaksanaan}

Berdasarkan perencanaan yang disusun ini pelaksanaan pembelajaran dilaksanakan sesuai dengan apa yang telah direncanakan. Pada siklus II, pembelajaran disajikan dalam 2x pertemuan. Pada bagian ini fokos pelaksanaan tindakan peningkatan pembelajaran pembelajaran IPS dengan pendekatan problem solving siklus II masih meliputi langkah-langkah pembelajaran dengan pendekatan problem solving secara keseluruhan.

Pada saat membangun pengetahuan baru siswa, guru sudah memberi waktu yang cukup untuk siswa berfikir setelah diberikan pertanyaan. Pada proses pembelajaran mengajukan pertanyaan untuk, mendorong,membimbing dan menilai kemampuan berfikir siswa, guru sudah bertanya bersifat menggali pengetahuan siswa. Dalam mengarahkan siswa untuk menyimpulkan pelajaran guru sudah membimbing siswa dalam menyimpulkan pelajaran secara runtun.

Dalam proses pembelajaran guru sudah menilai secara langsung. Dalam membangun pengetahuan siswa aktif dalam mengemukakan pendapat. Dalam mengajukan pertanyaan untuk memperoleh informasi /pengetahuan, siswa sudah berani dalam mengajukan pertanyaan. Dalam membimbing merumuskan masalah guru sudah mengajukan pertanyaan yang menggali dan menuntun dengan baik cara merumuskan masalah, Pada tahap merumuskan hipotesis pertanyaan yang diajukan guru sudah membantu peserta didik untuk merumuskan perkiraan jawaban. Siswa sudah menghargai pendapat setiap anggota kelompok, dalam membaca wacana siswa sudah menggali sumber data atau informasi secara efektif dan efisien, dalam merumuskan kesimpulan siswa sudah mendengarkan penjelasan dari guru. Dari hasil pengamatan observer pada saat 
pelaksanaan pembelajaran berlangsung pada siklus II skor yang diperoleh untuk aspek guru yaitu 88,8\%dengan kualifikasi sangat baik. Aspek siswa yaitu 86,7\% dengan kualifikasi baik.

\section{Pengamatan}

Pengamatan yang dilakukan pada penelitian ini meliputi pengamatan, terhadap hadap aktifitas guru dan siswa. Berdasarkan hasil observasi pengamatan terhadap Rencana Pelaksanaan Pembelajaran (RPP) pada siklus Iadalah $71 \%$ dengan kualifikasi cukup dan siklusII adalah $85,71 \%$ dengan kualifikasi baik. Terhadap peneliti sebagai guru dalam kegiatan pembelajaran pada siklus I adalah 77,05\% dengan cukup, sedangkan terhadap aspek siswa siklus I mendapat nilai 78,1\% dengan kualifikasi cukup. Pada siklus I diperoleh hasil penilaian 66,95\% dengan kualifikasi cukup dan siklus II mendapat nilai 81,30\% dengan kualifikasi baik.

\section{Refleksi}

Berdasarkan catatan pada lembar observasi dan diskusi peneliti dengan observer, pelaksanaan pembelajaran persebaran sumber daya alam pada siklus II dapat dikatakan sudah sesuai dengan yang diharapkan, dilihat dari kemampuan siswa dalam melewati tahapan-tahapan pendekatan problem solving dengan sempurna. Pada pelaksanaan siklus II ini siswa dibawa pada suasana kelas yang baru dan menyenangkan seperti yang dikemukakan oleh Bruner (dalam Isti 1999:327) "proses belajar mengajar akan berjalan dengan baik dan kreatif jika guru memberikan kesempatan kepada siswa untuk menentukan dan melakukan sesuatu".

Dilihat dari pelaksanaannya, pelaksanaan pembelajaran IPS dengan pendekatan problem solvingpada siklus II telah terlaksana dengan baik dan sesuai dengan perencanaan yang tersusun .Hasil observasi terhadap aktivitas guru dalam pelaksanaan pembelajaran terhadap aktivitas guru siklus II memperoleh nilai $88,8 \%$ dengan kriteria baik. Sedangkan aktivitas siswa dalam pelaksanaan terhadap aktivitas siswa siklus II memperoleh nilai $86,7 \%$ dengan kriteria baik. Keberhasilan pelaksanaan pembelajaran seperti yang dipaparkan diatas dapat dibuktikan dengan hasil belajar yang diperoleh siswa pada siklus II ini adalah 81,30 dengan kriteria baik.

\section{PEMBAHASAN}

\section{SIKLUS I}

Dari hasil penelitian pelaksanaan pendekatan problem solvingpada pembelajaran mengenal perkembangan teknologi produksi, komunikasi dan transportasi serta pengalaman menggunakannyapada mata pelajaan IPS dikelas IV sekolah dasar. Terungkap bahwa guru membuat perencanaan yang dimulai dengan membuat rancangan pembelajaran dalam bentuk Rencana Pelaksanaan pembelajaran (RPP) sesuai dengan komponen RPP menurut Rusman (2010:5)"Komponen RPP terdiri dari (I) identitas mata pelajaran, (2) standar kompetensi, (3) kompetensi dasar, (4) indicator, (5) tujuan pembelajaran, (6) materi ajar, (7) alokasi waktu, (8) metode pembelajaran, (9) kegiatan pembelajaran, (10) penilaian hasil belajar, dan (11) Sumber belajar".

RPP disusun sesuai dengan tahap pendekatan problem solving menurut Wina (2008:217) yaitu (1) adanya masalah yang jelas untuk dipecahkan, (2) merumuskan masalah, (3) merumuskan hipotesis atau jawaban sementara, (4) mencari data atau informasi untuk memecahkan masalah, (5) mencocokkan atau menguji kebenaran jawaban sementara, (6) menarik kesimpulan. Berdasarkan analisis data hasil observasi RPP pada siklus I diperoleh persentase rata-rata nilai $71 \%$. Hal ini menunjukkan bahwa kemampuan guru dalam merencanakan pembelajaran berdasarkan pendekatan $C T L$ berada dalam kriteria cukup.

Berdasarkan perencanaan yang telah disusun, pelaksanaan pembelajaran IPS pada siklus I dengan pendekatanproblem solvingbelumterlaksana dengan baik. Hal inidapat dilihat dari hasil observasi aktivitas guru dan siswa dalam pelaksanaan pembelajaran. Hasil observasi aktivitas guru dalam pelaksanaan pembelajaran dengan pendekatan problem solvingpada siklus I diperoleh rata-rata nilai 77,05\%, sedangkan hasil observasi pada aktivitas siswa dalam pelaksanaan pembelajaran IPS dengan pendekatan problem solvingsiklus I diperoleh nilai $78,1 \%$. Selanjutnya jika dilihat dari hasil belajar yang diperoleh siswa masih dibawah ketuntasan belajar yang diinginkan.

Dari analisis hasil penelitian siklus I, rat-rata nilai hasil belajar yang diperoleh siswa pada siklus I yaitu 66,95 dengan persentase ketuntasanperorangan65\%, Sedangkan menurut kunandar (2008:428), "Ketuntasan belajar yang ideal adalah 75\%. Dengan demikian, dapat disimpulkan bahwa pelaksanaan pembelajaran IPS dengan pendekatan problem solvingpada siklus I belum berhasil. 


\section{SIKLUS II}

Perencanaan pembelajaran pada siklus II sudah mencapai keberhasilan dengan baik .Pelaksanaan pembelajaran pada siklus II menunjukkan bahwa pembelajaran IPS dengan pendekatan problem solving pada siklus II sudah efektif. Dalam proses pembelajaran guru sudah menilai siswa secara langsung. Menurut Nasar(2006:115)"Hasil belajar melalui pendekatan problem solving diukur dengan berbagai cara seperti proses kerja ,hasil karya penampilan, rekaman, tes dan nilai". Soal yang diberikan guru sudah jelas mudah dimengerti .Dalam membangun pengetahuan siswa kurang aktif dalam mengemukakan pendapat. Seharusnya siswa lebih aktif karena menurut Nasar (2006:115) "Dalam pembelajaran menggunakan pendekatan problem solvingsiswa dilibatkan secara aktif dalam proses pembelajaran."

Dari hasil analisis data penelitian terhadap RPP pada siklus II diperoleh persentase skor rata-rata $85,71 \%$ dengan kriteria baik Dilihat dari pelaksanaannya, pelaksanaan pembelajaran IPS dengan pendekatan problem solving pada siklus II telah terlaksana dengan baik dan sesuai dengan perencanaan yang tersusun. Hasil observasi terhadap aktivitas guru dalam pelaksanaan pembelajaran diperoleh persentase $88,8 \%$ dengan kriteria baik. Sedangkan pada aktifitas siswa diperoleh persentase $86,7 \%$ dengan kriteria baik. Selanjutnya keberhasilan pelaksanaan pembelajaran seperti yang dipaparkan data diatas dapat dibuktikan dengan hasil belajar yang diperoleh siswa pada siklus II adalah 81,30.

\section{SIMPULAN DAN SARAN}

Pada tahap perencanaan siklus I ini masih ada beberapa kekurangan diantaranya materi belum sesuai dengan karakteristik siswa Pemilihan media belum sesuai dengan karakteristik siswa ,dan tekhnik pembelajaran belum sesuai dengan karakteristik siswa sehingga memperoleh nilai $71 \% \%$ dengan kualifikasi cukup semua kekurangan pada siklus I diperbaiki pada siklus II sehingga diperoleh nilai $85,71 \%$ dengan kualifikasi baik. Dengan demikian terjadi peningkatan dari siklus I ke siklus II.

Pada pelaksanaan siklus I masih ada kekurangan , diantaranya guru belum memberikan waktu yang cukup untuk siswa berfikir setelah diberi pertanyaan, dan siswa belum aktif dalam mengemukakan ide atau pendapat.Sehingga diperoleh penilaian aktivitas guru 77,05\% dengan kualifikasi cukup dan aktifitas siswa 78,1\% dengan kualifikasi cukup. Semua kekurangan pada siklus I tersebut diperbaiki pada siklus II sehingga aktifitas guru diperoleh nilai 88,8\% dengan kualifikasi baik dan aktifitas siswa 86,7\% dengan kualifikasi baik. Dengan demikian terjadi peningkatan dari siklus I ke siklus II. Hasil belajar dengan pendekatan problem solvingini dapat meningkat . Hal ini dapat dilihat dari rekapitulasi hasil belajar siswa siklus Idiperoleh66,95 pada siklus I Lebih rendah jika dibandingkan dengan rekapitulasi hasil belajar siswa siklus II yaitu 81,30.

Berdasarkan hasil dan temuan penelitian dengan pendekatan problem solving dalam pembelajaran sumber daya alam di kelas IV SD Negeri 21 Batang Anai, maka dikemukakan saran bahwa Guru hendaknya mampu menggunakan variasi dalam pelaksanaan pembelajaran dan dapat menerapkan pendekatan problem solvingini di sekolah dalam pembelajaran IPS.

Disamping itu ,pengeloaan kelas dan mengaitkan materi pembelajaran dengan kehidupan nyata siswa juga tidak bisa diabaikan, karena semuanya itu dapat menciptakan suasana belajar yang kondusif. Selain itu diharapkan kepada penulis /praktisi berikutnya, terutama guru-guru yang berminat melakukan PTK, agar penelitian berikutnya menggunakan pendekatan problem solvingdalam pembelajaran pada jenjang kelas lainnya.Bagi pembaca agar tulisan ini dapat memberikan wawasan dan pengetahuan,khususnya bagi pembaca yang akan melakukan PTK.

\section{DAFTAR RUJUKAN}

Alben Ambarita. (2006). Manajemen Pembelajaran. Jakarta: DIKTI.

Depdiknas. (2006). Kurikulum Tingkat Satuan Pendidikan Jenjang Pendidikan Dasar. Jakarta: BNSP.

Joko subagyo. (2006). Metode Penelitian Dalam Teori Dan Praktek. Jakarta: PT Rineka Cipta.

Kunandar. (2007). Guru Propesional. Jakarta:Grafindo Persada.

Mundilarto Rustam. (2008). Penelitian Tindakan Kelas. Tersedia dalam http://klinikpembelajaran.com/booklet/penelitian_tindakan_kls.pdf. Diakses tanggal 22 Maret 2011 
Rusman. (2010). Model-model Pembelajaran Mengembangkan Profesional Guru. Jakarta: PT Raja Grafindo Persada.

Wina Sanjaya. (2008). StrategiPembelajaran Berorientasi Standar Proses Pendidikan. Jakarta: Kencana Prenada Media Gro 